\title{
RESTRICTIONS AGAINST RAIL ENTRY INTO OTHER TRANSPORTATION FIELDS
}

\author{
Peter T. Beardsley*
}

When Congress provided for federal regulation of interstate motor vehicle transportation, it took steps to bar railroad entry into the field of unrestricted motor carriage. That policy, consistent with the basic antitrust philosophy expressed in the Sherman Act of $1890^{1}$ and other federal antimonopoly statutes, was, and is, sound and should continue in effect.

On the Archives Building in Washington, D. C., are two inscriptions. One admonishes: "Study the Past"; the other informs that "What Is Past Is Prologue." A study of the past, it is submitted, will demonstrate vividly the need for protecting other forms of transportation from wholesale rail encroachment.

The railroads throughout the country, individually and through their associations, have for some years contended that they are the victims of an outmoded regulatory scheme and, as a result, are not able to render the quality of service of which they are capable, provided only that their "managerial discretion" were allowed free rein. All they ask, they say, is the opportunity fully and fairly to compete with other modes of transportation, including the privilege of owning and operating such other modes. Most of their ammunition, of late, seems to be directed at this latter target, referred to by them variously as "common ownership," "diversification," and lately as "one-package transportation." One of the commonest arguments made in support of the rail premise that they should be allowed free entry into other forms of transportation is the need for coordination in transportation service.

\section{I}

\section{Congressional Policy}

There is ample opportunity for coordination of service under present transport laws. The Interstate Commerce Act authorizes joint-rate and through-route arrangements between different types of carriers. ${ }^{2}$ Although the trucking industry stands ready to work with the railroads in the performance of coordinated rail-truck service, the railroads generally, with a few scattered exceptions, have followed a policy of refusing to enter into joint-rate and service arrangements with motor carriers. This refusal was at first the result of concerted action by the railroads that culminated in a series of resolutions adopted by the Association of American Railroads that

- LL.B. 194r, National University. Member of the District of Columbia bar. General Counsel, American Trucking Associations, Inc., Washington, D.C.

${ }^{2} 26$ Stat. 209,15 U.S.C. $\$ \$ 1-7$ (1952).

${ }_{49}^{9}$ Stat. $55^{8}$ (1935), 49 U.S.C. $\$ 3$ I 6 (c) (1952). 
forbade member roads from establishing joint rates with common carrier bus or truck lines. As a result of an antitrust action brought by the Department of Justice, however, these resolutions were rescinded; but the railroads, generally speaking, have continued to follow the policy which the resolutions established. It would be ironic, indeed, if the railroads were rewarded for their failure to enter into joint-rate and through-route arrangements with motor carriers by a change in the law that would permit them to own and operate all forms of transportation, with all the monopolistic vices inherent in any such scheme.

The policy against allowing common control of competing media of transportation was well-established long before interstate transportation by motor vehicle was brought under federal control. The Panama Canal Act of $1912^{3}$ and the legislative debates thereon disclose a crystal-clear congressional intent to keep each form of transport independent of ownership or control by other forms. The report of the House Committee dealing with the legislation noted: ${ }^{4}$

The proper function of a railroad corporation is to operate trains on its tracks, not to occupy the waters with ships in mock competition with itself, which in reality operate to the extinction of all genuine competition.

The above-quoted language was not merely the refection of "ivory tower" thinking; rather it represented the view of practical men whose duty it was to advance the interests of the entire public in the regulation of transportation and whose experience with railroad operations up to that time motivated the passage of the law in question. Although the Panama Canal Act of rgr2 absolutely prohibited rail control of water lines operated through the Canal, it allowed rail control of lines not so operated, if the "Commission shall find that the continuance or acquisition of such ownership . . . will not prevent such [water carrier] from being operated in the interest of the public and with advantage to the convenience and commerce of the people. ..." Shortly after passage of the Panama Canal Act, various railroads owning or having an interest in water lines operating on the Great Lakes filed petitions seeking the right to continue the relationship. In Lake Line Applications Under Panama Canal Act, the Interstate Commerce Commission said:"

These boat lines under the control of the petitioning railroads have been first a sword and then a shield. When these roads succeeded in gaining control of the boat lines which had been in competition with paralleling rails in which they were interested and later effected their combination through the Lake Line Association by which they were able to and did drive all independent boats from the through lake-and-rail transportation, they thereby destroyed the possibility of competition with their railroads other than such competition as they were of a mind to permit. Having disposed of real competition via the lakes, these boats are now held as a shield against possible competition of new independents. Since it appears from the records that the railroads are able to operate their boat lines at a

${ }^{8} 37$ Stat. 566,49 U.S.C. $\$ 5$ (I4), (15), (I6) (1952).

'House Comm. on Interstate and Foreign Commerce, Operation of the Panama Canal, H.R. Rep. No. 423, 62d Cong., 2d Sess. 12 (1912).

${ }^{5} 37$ Stat. 566,49 U.S.C. $\$ 5(16)$ (1952).

${ }^{\circ} 33$ I.C.C. $699,7^{16}$ (1915). 
loss where there is now no competition from independent lines, it is manifest that they could and would operate at a further loss in a rate war against independents. The large financial resources of the owning railroads make it impossible for an independent to engage in a rate war with a boat line so financed.

From a consideration of all the circumstances and conditions disclosed by the respective records herein, the Commission is of opinion and finds that none of the several existing specified services by water herein concerned is being operated in the interest of the public or is of advantage to the convenience or commerce of the people within the meaning of the act, and that an extension and a continuance thereof will prevent, exclude, and reduce competition on the great lakes. The application of each of the petitioners herein is therefore denied, effective December 1, I9I5. An order will be entered accordingly.

By section 213 of the Motor Carrier Act of 1935 (now incorporated in section five of the Interstate Commerce Act), ${ }^{7}$ the ICC was authorized to approve the acquisition of control of a motor carrier by another such carrier upon a finding that "the transaction proposed will be consistent with the public interest." However, the law provided that if the purchaser was "a carrier other than a motor carrier," the ICC was precluded from approving the transaction unless it would (a) "promote the public interest by enabling such carrier other than a motor carrier to use service by motor vehicle to public advantage in its operations," and (b) "not unduly restrain competition."8

In referring to these provisions of the law, those charged with the responsibility for the legislation in the House and Senate clearly indicated the congressional intent to maintain the independence of the newly-regulated industry. Mr. Sadowski, the Chairman of the Subcommittee of the House Committee on Interstate and Foreign Commerce, said: ${ }^{9}$

I will say in this respect that it is the intent, and it is important to the welfare and progress of the motor-carrier industry, that the acquisition of control of the carriers be regulated by the Commission so that the control does not get into the hands of other competing forms of transportation, who might use the control as a means to strangle, curtail, or hinder progress in highway transportation for the benefit of the other competing transportation.

Senator Wheeler, Chairman of the Senate Committee on Interstate Commerce, spoke in a similar vein $:^{10}$

With this limitation, it will be possible for the Commission to allow acquisitions which will make for coordinated or more economical service and at the same time to protect the public against the monopolization of highway carriage by rail, express, or other interests.

It is interesting to note that Congress, by the Transportation Act of $1940,{ }^{11}$ removed any bar to the acquisition of a motor carrier by a water carrier, but continued in full force the restriction against rail operation of motor vehicles except in

749 Stat. 543, 49 U.S.C. $\$ 5(2)(b)$ (I952).

79 Cong. Rec. I2206 (I935).

${ }^{8}$ Ibid.

${ }^{11} 54$ Stat. 898,49 U.S.C. $\$ \$ 1$ et seq. (1952).

${ }^{10}$ Id. at 5655 . 
what has come to be known as "auxiliary and supplemental" service. Here, it would seem, was recognition that although there was little danger that water carriers would be able to gain control of the motor-carrier industry, there was no basis for a similar assumption with respect to the vastly larger and far more financiallypowerful railroad industry.

II

\section{The Commission's Approach}

It is not the purpose of this article to discuss in detail all of the important court and ICC decisions dealing with railroad efforts to perform all-out trucking operations; reference to a few of them will suffice.

The landmark decision in this field is the so-called Barker case, ${ }^{12}$ decided in 1936. There, a motor-carrier subsidiary of the Pennsylvania Railroad sought authority to acquire the operating rights of an independent motor carrier. Through the acquisition, the rail affliate intended to perform two distinct types of motor-carrier operations. On the one hand, it proposed a service fully coordinated with that of its rail parent; on the other, it proposed to conduct operations completely divorced therefrom. The ICC, Division Five, refused to sanction the proposed purchase, and in so doing, it set forth its reasons in what has become the classic statement in support of the proposition that railroads should not be allowed to encroach upon the motorcarrier field: ${ }^{13}$

While we have no doubt that the railroad could, with the resources at its command, expand and improve the partnership service and that, so far as numbers are concerned, there is now an ample supply of independent operators in the territory for the furnishing of competitive service, we are not convinced that the way to maintain for the future healthful competition between rail and truck service is to give the railroads free opportunity to go into the kind of truck service which is strictly competitive with, rather than auxiliary to, their rail operations. The language of section 213 , above quoted, is evidence that Congress was not convinced that this should be done. Truck service would not, in our judgment, have developed to the extraordinary extent to which it has developed if it had been under railroad control. Improvement in the particular service now furnished by the partnership might flow from control by the railroad, but the question involved is broader than that and concerns the future of truck service generally. The financial and soliciting resources of the railroads could easily be so used in this field that the development of independent service would be greatly hampered and restricted, and with ultimate disadvantage to the public.

In a subsequent decision in the Barker case, the precise limits of rail operation of motor vehicles were spelled out: ${ }^{14}$

Approved operations are those which are auxiliary or supplementary to train service. Except as hereinafter indicated, nonapproved operations are those which otherwise compete

${ }^{12}$ Pennsylvania Truck Lines, Inc.-Control-Barker Motor Freight, Inc., I M.C.C. Ior (1936).

${ }^{13}$ Id. at III-r2.

${ }^{14}$ Pennsylvania Truck Lines, Inc.-Control-Barker Motor Freight, Inc., 5 M.C.C. 9, I1-12 (1937). 
with the railroad itself, those which compete with an established motor carrier, or which invade to a substantial degree a territory already adequately served by another rail carrier.

Thus, at the very outset of federal regulation of the motor-carrier industry, the ICC construed the governing statute as requiring it to insure against all-out truck operations by railroads, competitive with independent motor carriers and, indeed, with their own train service.

As noted, the Barker case involved a purchase application, bringing into play the specific statutory language of section 2I3 of the Motor Carrier Act of I935, requiring, inter alia, a finding by the ICC that the rail applicant would "use service by motor vehicle to public advantage in its operations" before the purchase could be authorized. What about a so-called extension application by a railroad under section 207 ? $^{15}$ In other words, what if a railroad first purchased a motor-carrier operation subject to restrictions as required by section $2 r_{3}$ and subsequently sought to have the restrictions removed by virtue of a section 207 proceeding? Although the express limitations contained in section $2 \mathrm{r}_{3}$ were not repeated in section $20 \%$, the ICC, in the leading case of Kansas City Southern Transport Co., Inc., Common Carrier Application, ${ }^{16}$ held, in $193^{8}$, that the principles of the Barker case were equally applicable to section 207 proceedings.

Through the years, the ICC consistently has construed the law as requiring that rail operation of motor vehicles, except in a handful of cases-distinguishable and relatively unimportan ${ }^{17}$-be restricted to auxiliary and supplemental service, whether the service resulted from applications filed pursuant to section 213 or section 207 . The only major exception to the requirement that railroads be limited to so-called auxiliary and supplemental trucking operations is the recent decision of the ICC in Rock Island Motor Transit Co. Common Carrier Application. ${ }^{18}$ In that proceeding, the ICC held that the "special circumstances" of the case, the failure of the independent motor-carrier protestants to provide adequate service to the small Iowa communities involved, justified a grant of unrestricted authority to the rail-subsidiary applicant. Even so, the ICC made it clear that it was not abandoning its longcontinued practice of restricting railroad truck operations to auxiliary and supplemental service when it said $:^{19}$

The findings hereinafter made are not to be construed as an abrogation of the policy established in Kansas City S. Transport Co., Inc., Com. Car. Application. . . . They represent an exception to that policy justified by the evidence in this proceeding. In other words,

${ }^{25} 49$ Stat. 55I (1935), 49 U.S.C. $\$ 307$ (1952).

${ }^{10}$ ro M.C.C. 221 (1938).

${ }^{17}$ The exceptions fall into three categories:

(a) Where the service is to a point not on the rail line, not adequately served by any other carrier, rail or motor. See, e.g., Interstate Transit Lines Ext.-Verdon, Nebr., 1o M.C.C. 665, 667 (1938).

(b) Where the service is to be tacked to existing service already subject to appropriate restrictions. See, e.g., Rock Island Motor Transit Co. Ext.-Wellman, Iowa, 3I M.C.C. 643 (1942).

(c) Where the truck service constitutes the major portion of the applicant's business, the rail service having become unimportant. See, e.g., ET \& WNC Transp. Co.-Control-The Inter City Trucking Co., 60 M.C.C. 620 (1954).

${ }^{18} 63$ M.C.C. $9 \mathrm{I}$ (1954). 
such findings do not establish a precedent. Each case of this character must be determined upon the facts and circumstances disclosed by the evidence.

Thus, it is clear that the congressional policy, embodied in section 213 of the Motor Carrier Act of 1935, requires, except in special circumstances, that railroad-truck operations be limited to auxiliary and supplemental service, whether a particular application involves a purchase under section five or an extension subject to section 20\%. We turn next to the question of whether the law should remain as is, or whether its amendment to permit railroads to own and operate all facilities of transportation would be in the public interest.

\section{III}

\section{Is Amending Legislation Needed?}

The motor-carrier industry genuinely fears the possibility of unrestricted truck operations by railroads generally. This fear is based not on vague apprehension, but on concrete evidence of past rail activities which suggest that their tactics over the years have had but one objective: that of crippling their competitors by any means at hand, fair or otherwise. In I94I, the Senate Committee on Interstate Commerce, after an exhaustive investigation of railroads, holding companies, and affiliated companies, issued a lengthy report, which, among other things, noted:20

In one instance a transportation study, financed by a large railroad system and widely distributed in public schools, made no mention of the fact that railroad funds were behind it. Instead it gave the impression that it was the work of a Government-sponsored institution and hence an impartial survey. Another foundation, organized at the suggestion of railroad executives and financed in part by railroad treasuries, distributed its publications to hundreds of thousands of persons. Material in these publications was subject to the censorship of railroad officials and was characterized by them as "prorailroad" in its viewpoint. Nevertheless, this foundation described itself as an "independent organization" interested only in the "presentation of facts" and failed to reveal in any instance that it received financial and other support from railroads.

Another organization also presented itself to the public as a "neutral agency," an "unbiased association" and an "independent organization." Here again investigation disclosed that the organization was brought into being primarily through the railroads, was heavily financed by railroads, and was working to protect railroads from the competition of other forms of transportation and Government regulation. Directors of this organization were selected according to their "railroad attitude," and at least some of the so-called educational material it put out originated in the offices of railroad executives who frankly admitted that such material if sponsored openly by the railroads would be discounted as too biased.

Railroads and railroad associations have spent large sums in lobbying for antitruck legislation. Seldom revealing their true role, they have worked "under cover" behind the fronts of taxpayers' groups, transportation associations, safety councils, and other organized groups. Among the measures thus secretly sponsored have been laws increasing taxes on

${ }^{20}$ Senate Comm. on Interstate Commerce, Investigation of Reilroads, Holding Companies, and Affiliated Companies, S. REP. No. 26, 77th Cong., Ist Sess. pt. 2, at 67-68 (1941). 
trucks, limiting the size and weight of trucks and trailers, and tightening insurance and license requirements.

Enforcement of such legislation by railroads has been promoted by admittedly "deceptive" methods. Intricate spy systems have been set up to catch trucks and truckers in violation of the laws. One man subsidized by railroad funds disguised himself as a salesman of scales for weighing trucks. Another concealed his railroad connection by pretending that his major interest was in getting truckers arrested so that he could supply them with with bail bonds. One agent secured valuable information for the railroads as a representative of an "independent" weekly. Staffs of railroads were organized into a vast "intelligence system" for relaying information regarding truck movements. Rewards were offered to officers of the law to arrest truckers. Fictitious complaints from constituents were used in bringing pressure to bear on legislators. Material furnished free to newspapers and supposedly coming from a disinterested source gave wide publicity to the railroads' point of view. Research studies presented as the work of impartial engineers or taxpayers' groups, but actually financed by the railroads, purported to show the damage done to highways by trucks and the inadequacy of taxation on trucks.

In their legislative work the railroad associations have called on the staffs of railroads, chambers of commerce, shippers' groups, and many others to testify in behalf of the railroads and to urge action on legislators. In many instances such groups have been paid by the railroads for their services and have then urged their views on Congressmen as those of disinterested bodies unconnected with the carriers.

For those who think that the railroads have, in later years, adopted a more enlightened approach respecting the scope of competitive activities, a reading of the decision in Noerr Motor Freight, Inc. $v$. Eastern Railroad Presidents Conference ${ }^{21}$ is recommended. Again, after exhaustive investigation, the United States District Court for the Eastern District of Pennsylvania issued a comprehensive opinion containing the following findings: ${ }^{22}$

I. That the rail defendants and Byoir, their public relations agency, "entered into a conspiracy in unreasonable restraint of trade, the nature and purpose of which was to injure the truckers in their competitive position in the long-haul freight industry in the northeastern section of the United States."

2. That the immediate purpose of the conspiracy "was to create public resentment to the truckers, not only in the minds of the general public but in the minds of those who utilized the services of the trucks and in such a manner as to interfere with business relations between shippers and truckers."

3. That the railroads "[i]nstead of meeting the [truck] competition in the field and giving the shippers what the shippers wanted ... determined upon another course of action-to injure and/or destroy the truckers and thereby force the shippers to their detriment to continue to use the railroads."

4. That the actions of the railroads and their co-conspirators "destroyed to a large extent the public confidence which the truckers had earned by their own efforts and which they might have won additionally, especially in the light of the

${ }^{21}{ }_{55}$ F. Supp. 768 (E.D. Pa. I957), aff'd, TRADE REG. REP. I69,546 (3d Cir. I959).

${ }^{32}$ Id. at $80 \mathrm{~g}-\mathrm{II}$. The record in the case was comprised of over 6,000 pages and 968 exhibits. 
innumerable beneficial accomplishments of the truckers in the field of long-haul transportation."

5. That "the evidence in this case clearly shows that, except for a small segment, the truckers are decent law-abiding citizens who obey the law, but as a result of this campaign they were categorized as law-breakers, road-hoggers, completely indifferent to the safety of others on the highway and moochers on the public through failure to pay their way."

6. That "overt acts to accomplish the objectives of this conspiracy were committed among others in the states of Connecticut, Indiana and Illinois. This feature is mentioned ... to show that this was not a series of individual conspiracies but was one large evergrowing conspiracy with the single objective of 'improving the competitive position of the railroad in the field of transportation,' but by the illegal means of limitation of or destruction of the trucking industry."

When the experience of motor carriers with the rail competitive efforts disclosed by the cited Senate report and the Noerr case is considered, the trucking industry can well be expected to look with trepidation upon any change in the law which would permit railroads generally to engage in unrestricted truck service.

If the aim of the railroads were simply to substitute truck service for their train service and literally to abandon entirely their rail operations, that would be one thing. The trucking industry, having built, in many respects, a "better mouse-trap," would undoubtedly be able to hold its own with rail-operated truck lines. But any such assumption of railroad purpose is, of course, preposterous. The rails, having a net investment of over $\$ 27,000,000,000$ in plant and equipment, could scarcely be expected to abandon that field. What then, would they do if they were able to conduct unrestricted truck operations throughout the length and breadth of their present systems?

It should be remembered that every pound of additional freight that railroads would handle in their truck operations would be freight that they would not handle in their train service. If all they seek to do is improve their over-all rail service by eliminating slow, local "way trains" and things of that nature, the present law, as administered by the ICC, affords them all the opportunities they need to put such practices in effect. So it must be assumed that once restrictions against all-out truck service were removed, the railroads would aggressively solicit vast tonnages of traffic to be moved in all-motor service operated by their subsidiaries. On the other hand, it seems plain that the railroads' ultimate objectives, because of their tremendous investment, is to get all traffic, or as much of it as possiblc, "back on the rails." In this connection, there is quoted below a revealing colloquy between Senator Purtell and D. B. Jenks, President of the Chicago, Rock Island, \& Pacific Railroad, during the course of some recent hearings on problems of the railroads: ${ }^{23}$

${ }^{23}$ Hearings Before the Subcommittee on Surface Transportation of the Senate Committee on Interstate and Foreign Commerce on Problems of the Railroads, 85th Cong., 2d Sess. pt. I, at 588 (1958). 
Sen. Purtell. What I am trying to point out, sir, is that if we followed your suggestion, and the railroad companies were allowed to enter all fields of transportation, unencumbered by any special restrictions, then we would be likely to find that you are able to enter the trucking field, and you enter the air transportation-and that of course is a growing industry-and to the extent that you engage in that, to meet that type of competition, to that extent you reduce the importance of the railroads themselves in transporting goods in peacetime.

Mr. Jenks. No, I don't think so at all because actually we would use it to bring more traffic to the rails, to get a better utilization of the railroads, to do the thing best that we can do best.

Thus, it would seem, the ultimate purpose of rail entry into the fields of other forms of transportation would be to reduce those other forms to the status of rail feeder lines, in order, as stated by Mr. Jenks, "to bring more traffic to the rails." This aim, however, could only be accomplished if the railroads were successful in reducing their independent motor, water, and air competitors to impotency. Assuming that "what is past is prologue" and bearing in mind the vast financial resources of the railroads, it can logically be expected that they would use their subsidiaries as "fighting ships" to eliminate or render ineffectual their independent competitors in the fields of nonrail transportation. Once this had been accomplished, the railroads could then proceed to their ultimate objective- "to bring more traffic to the rails" by using their subsidiaries as feeder lines.

The area reached by the railroads' lines, in the aggregate, is such that they would be able, by interchanging freight between their motor subsidiaries, to reach every point of any commercial importance whatever throughout the country. It seems reasonable to assume that the railroads, once they were permitted to perform completely unrestricted truck service, would, wherever possible, limit the interchange of traffic moving in their motor service to their own subsidiaries. ${ }^{24}$ Since, at the present time, although the railroads freely interchange traffic with each other they generally avoid any interchange with motor carriers, it seems entirely unlikely that they would permit their subsidiaries to do otherwise.

Of course, the few rail subsidiaries which today can perform unrestricted truck service (largely as a result of having conducted such service prior to the passage of the Motor Carrier Act of 1935) do interchange traffic with independent motor carriers. But their reason for so doing is undoubtedly because only through such interchange can the shipments involved move in all-motor service, as desired by the shippers, from origin to destination. Once the present situation, where only a few rail-

\footnotetext{
${ }^{22}$ E.g., in a proceeding in which the Great Northern Railway seeks the removal of all restrictions in its truck certificates which prohibit all-motor transportation between Williston, North Dakota, and points in Montana, and between designated points in the latter state, the hearing examiner's report notes: "For example, if the restrictions are removed, Burlington Truck Lines can originate traffic at Denver, transport it to Billings, on truck billing and at truck rates, and interchange it with Great Northern for delivery to such points as Great Falls, Havre, Shelby, and any other points now served by the Great Northern Railway." Great Northern Railway Co.-Modification of Certificates, No. MC-28573 (Sub.-No. I2), ICC, May 28, x959. The "Burlington Truck Lines" referred to is the motor subsidiary of the Chicago, B. \& Q. Railway Co.
} 
roads have anything like extensive rights to perform all-out truck service, were changed to afford similar rights to all railroads, the independent motor carriers know full well that the railroads would make an all-out effort to restrict their interchange operations among themselves only. This would be accompanied by an equally in. tense effort to monopolize all the local motor traffic moving between points on the railroads' individual systems. These efforts, in turn, would be bolstered by an intensive rate-cutting campaign that would have as its purpose the removal of effective competition by independent motor carriers. It need hardly be argued that only the rail subsidiaries could long afford to handle large segments of traffic at less, or little more than, the bare-bones cost of providing the service and still continue as an effective instrument of motor transport. To paraphrase from the Lake Line Applications case: "The large financial resources of the owning railroads [would] make it impossible for an independent to engage in a rate war with a [motor] line so financed." If, despite their efforts to eliminate effective competition by rate-cutting activities, a few independent motor carriers remained on the scene, the railroads could undoubtedly, if they so desired, eliminate them through the simple expedient of buying them out.

\section{ConcLusion}

The present transportation law imposes no obstacles to coordinated service supplied by independent agencies within the various modes of transport. History shows that, given the opportunity, the railroads have used control of other transportation media to drive independent carriers out of business and that their operation of such captive lines has been contrary to the public interest. Subsequent rail activities afford no reason for belief that the railroads would use unrestricted authority to conduct operations in other fields of transport for public benefit. If permitted free entry into the motor-carrier field, they could, and probably would, use their vastly superior financial power to underwrite rate-cutting activities, with the immediate objective of eliminating independent trucking operations, at the same time limiting interchange of traffic to their own motor subsidiaries. Once these efforts had succeeded, the rails would then be free to take the last step in their over-all program, the bringing of traffic "back to the rails" in order to protect their heavy investment in rail plant and facilities.

On more than twenty occasions since the passage of the Panama Canal Act in I912. Congress has specifically considered the question of ownership of one mode of transportation by another. In each instance, Congress has rejected proposals which would allow such ownership. This is no time to turn back the clock. The present restrictions against rail entry into the fields of other forms of transport should be maintained-indeed, strengthened. 